\title{
Molecular diversity and microsatellite polymorphism of modern maize hybrids
}

\author{
Sanja Mikić* · Ljiljana Brbaklić · Dušan Stanisavljević · Ankica Kondić-Špika · Goran Bekavac · \\ Bojan Mitrović · Dragana Trkulja · Milan Mirosavljević
}

Institute of Field and Vegetable Crops, Maksima Gorkog 30, 21000 Novi Sad, Serbia

\begin{abstract}
Summary: The aim of this study was to estimate genetic diversity of 97 modern maize hybrids cultivated in Serbia with 12 microsatellite markers. In total, 89 alleles were detected, with the average of 7.4 alleles per locus. The polymorphic information content ranged from 0.42, for umc1792, to 0.81, for dupssr10, with an average of 0.64. The pairwise relatedness Ritland's values varied between 0.787 and -0.129 . Eight markers were sufficient to differentiate hybrids with unique genotypes. A principal coordinate analysis distinguished early and late maturing groups of hybrids, although the observed differentiation between groups was low (Fst $=0.4 \%$ ). Two markers, bnlg1556 and umc1075, contributed most to the discrimination between early and late genotypes. The values of parameters of molecular genetic diversity were higher in early than in late maturing hybrids, indicating broader genetic basis of the former. A high level of polymorphism of the markers indicates their suitability for fingerprinting.

Key words: fingerprinting, genetic diversity, genotyping, hybrids, maize, markers, microsatellites, polymorphisms
\end{abstract}

\section{Introduction}

Maize (Zea mays L.) exhibits a huge diversity in forms, subspecies, varieties and races, being highly variable in both phenotype and genotype (Buckler et al., 2006). The importance of such diversity is widely recognised as a source of favourable alleles for traits of interest that breeders seek for crop improvement. The diversity also ensures the stability of production under unfavourable and unexpected factors of abiotic and biotic stress. Furthermore, understanding of genetic diversity and relatedness among maize germplasm is crucial for its identification, classification and, ultimately, its efficient use in breeding programmes (Prasanna, 2012).

Despite the great genetic diversity of maize, some concerns were raised regarding the reduction of diversity among modern hybrids widely grown on farms. This diversity decline is believed to be caused by the multiple use of few elite lines as parents for hybrid development, driven by a constant demand for hybrids with stable and higher yield (Reif et al., 2005). Moreover, it was estimated that only six or seven inbred

Corresponding author:

sanja.mikic@ifvens.ns.ac.rs

Acknowledgment:

This study was funded by the Ministry of Education, Science and Technological Development of the Republic of Serbia, under the project TR31073. lines were identified to be founders of modern maize hybrids (Technow et al., 2014).

However, other studies showed that genetic diversity had been substantially reorganized with the introduction of maize hybrids with only a limited reduction (Tenaillon \& Charcosset, 2011; van de Wouw et al., 2010). Guzman and Lamkey (2000) did not find any significant loss in additive genetic variance for maize yield during five cycles of selection, while the results of Tabanao and Bernardo (2005) implied that non-additive gene effects in elite maize inbreds accounted for an excess of genetic variance in small populations. In addition, Duvick (2001) argued that the genetic components of contemporary hybrids had changed every year, since they had been extracted from large and diverse breeding pools containing an increased built-in genetic diversity yet to be exploited.

Traditionally, the pedigree data have been one of the main tools to elucidate genetic composition and to estimate genetic distances and diversity of breeding material, providing breeders with valuable information for designing breeding schemes and planning crosses. Nevertheless, the hybrid pedigree data are often unavailable or uncompleted, being rather difficult to trace back to the founder germplasm. Considering high correlations between genetic distances obtained from molecular and pedigree data (Smith et al., 1992), molecular markers may facilitate genetic diversity assessment of hybrid maize. Simple sequence repeat 
markers (SSRs) or microsatellites are a marker system of choice for genetic characterisation of many crop species. Due to their abundance, high polymorphism, co-dominant nature and relatively low cost, SSRs prove to be a useful and reliable tool for assessing maize diversity, performing fingerprinting and validating pedigree data.

The aims of this study were 1) to estimate the genetic diversity of the contemporary maize hybrids available on market and cultivated on farms in Serbia, 2) to evaluate the polymorphism and suitability of a set of SSRs for molecular characterization of commercial maize hybrids, 3) to determine the minimum number of markers reliable for distinguishing modern maize hybrids and identifying unique genotypes, 4) to measure the ability of markers to show associations and to group hybrids using principal coordinate analysis, 5) to assess genetic diversity parameters of the analysed hybrid groups and 6) to find a correlation between genetic distance obtained using microsatellite markers and genetic distance expected on the basis of known pedigrees.

\section{Materials and Methods}

Ninety seven contemporary maize hybrids, ranging from 200 to 700 FAO maturity groups, were selected for the molecular analysis, according to their presence on farmers' fields in Serbia and availability of their seeds on the market. Regarding the hybrids' maturity, four hybrids belonged to $200 \mathrm{FAO}$ group, 16 to $300 \mathrm{FAO}$ group, 21 to 400 FAO group, 24 to 500 FAO group, 26 to $600 \mathrm{FAO}$ group and six to $700 \mathrm{FAO}$ maturity group.
Twenty nine hybrids were developed in three Serbian organisations, whereas 68 hybrids were from 11 international organisations (institutes or companies).

The DNA was extracted from 7-day old seedlings by sampling 5 plants in a bulk. The modified CTAB method was used for extracting DNA and twelve microsatellite markers were selected based on their good amplification and unambiguous scoring (Table 1). The forward primers were labelled with four fluorescent dyes to allow combined analysis of differently labelled polymerase chain reaction (PCR) products. The PCR mix contained $25 \mathrm{ng}$ of genomic DNA, $0.2 \mathrm{mM}$ dNTP, $1 \times$ Taq buffer with $\mathrm{KCl}, 2$ $\mathrm{mM} \mathrm{MgCl}, 1 \mathrm{U}$ Taq polymerase and $0.5 \mathrm{pmol}$ of each primer. The PCR programmes were run under following conditions: DNA denaturation at $94{ }^{\circ} \mathrm{C}$ for $5 \mathrm{~min}$, followed by 38 cycles at $94{ }^{\circ} \mathrm{C}$ for $30 \mathrm{~s}$, annealing at 53,56 or $58{ }^{\circ} \mathrm{C}$, depending on the primer pair (Table 1), for $45 \mathrm{~s}$, extension at $72{ }^{\circ} \mathrm{C}$ for $45 \mathrm{~s}$ and the final extension for 10 min at $72{ }^{\circ} \mathrm{C}$. The reaction volume for DNA fragment analysis contained $2 \mu \mathrm{l}$ PCR products, $0.2 \mu \mathrm{l}$ GeneScan 500 LIZ size standard and $7.8 \mu \mathrm{l} \mathrm{Hi-Di}$ formamide. The separation of PCR products were performed by capillary electrophoresis on ABI Prism 3130, while the allele scoring was done using Gene Mapper Software v.4.0 (Applied Biosystems).

Quality control measures were taken to obtain and interpret data accurately. Duplicate samples were used to assess reproducibility rate, samples with lower quality scans were repeated and negative (master mix without DNA) controls were included to avoid detection of genotyping artefacts and sample failures.

Table 1. Chromosome bins, sequences, annealing temperatures and repeat motifs of 12 analysed microsatellites

\begin{tabular}{|c|c|c|c|c|}
\hline Locus & $\operatorname{Bin}$ & Forward and reverse primers & Annealing temp. $\left({ }^{\circ} \mathrm{C}\right)$ & Repeat motif \\
\hline dupssr26 & 1.04 & $\begin{array}{l}\text { 5'-GTCGGAGCACTCCAAGAC-3' } \\
\text { 5'-CTTCTCGCTCATCAGCTTAAA-3' }\end{array}$ & 53 & (GA)23 \\
\hline bnlg1556 & 1.07 & $\begin{array}{l}\text { 5'-ACCGACCTAAGCTATGGGCT-3' } \\
\text { 5'-CCGGTTATAAACACAGCCGT-3' }\end{array}$ & 53 & $\mathrm{AG}(18)$ \\
\hline phi083 & 2.04 & $\begin{array}{l}\text { 5'-CAAACATCAGCCAGAGACAAGGAC-3' } \\
\text { 5'-ATTCATCGACGCGTCACAGTCTACT-3' }\end{array}$ & 56 & AGCT \\
\hline bnlg1520 & 2.09 & $\begin{array}{l}\text { 5'-TCCTCTTGCTCTCCATGTCC-3' } \\
\text { 5'-ACAGCTGCGTAGCTTCTTCC-3' }\end{array}$ & 53 & $\mathrm{AG}(22)$ \\
\hline umc1025 & 3.04 & $\begin{array}{l}\text { 5'-GCTCCACTTCCACCCTGATATG-3' } \\
\text { 5'-CGCTAATGTCCCCATTGATGAT-3' }\end{array}$ & 56 & (CT)11 \\
\hline umc1109 & 4.01 & $\begin{array}{l}\text { 5'-GCAACACAGGACCAAATCATCTCT-3' } \\
\text { 5'-GTTCGGTCCGTAGAAGAACTCTCA-3' }\end{array}$ & 56 & $(\mathrm{ACG}) 4$ \\
\hline$b n \lg 2291$ & 4.06 & $\begin{array}{l}\text { 5'-CCTCTCGATGTTCTGAAGCC-3' } \\
\text { 5'-GTCATAACCT'TGCCTCCCAA-3' }\end{array}$ & 53 & $\mathrm{AG}(17)$ \\
\hline dupssr10 & 5.04 & $\begin{array}{l}\text { 5'-AGAAAATGGTGAGGCAGG-3' } \\
\text { 5'-TATGAAATCTGCATCTAGAAATTG-3' }\end{array}$ & 53 & $\mathrm{AC}(22)$ \\
\hline umc1792 & 5.08 & $\begin{array}{l}\text { 5'-CATGGGACAGCAAGAGACACAG-3' } \\
\text { 5'-ACCTTCATCACCTGCAACTACGAC-3' }\end{array}$ & 58 & $(\mathrm{CGG}) 5$ \\
\hline umc1075 & 8.01 & $\begin{array}{l}\text { 5'-GAGAGATGACAGACACATCCT'TGG-3' } \\
\text { 5'-ACATT'TATGATACCGGGAGTTGGA-3' }\end{array}$ & 56 & (ATTGC) 5 \\
\hline bnlg162 & 8.05 & $\begin{array}{l}\text { 5'-ACTAGCAGCAGTAAACCTAATAAGGA-3' } \\
\text { 5'-CAAGTAGCTAGCAGTCATTTGCAGTGT-3' }\end{array}$ & 56 & $\mathrm{~N} / \mathrm{A}$ \\
\hline bnlg1209 & 9.04 & $\begin{array}{l}\text { 5'-GTCCCGGGCAGAATAATACC-3' } \\
\text { 5'-T'TCCTCCTTGAAGTGCTCGT-3' }\end{array}$ & 53 & $A G(12)$ \\
\hline
\end{tabular}


Table 2. Parameters of genetic diversity in maize hybrids obtained with 12 microsatellites

\begin{tabular}{lcccccccc}
\hline Locus & $\mathrm{Na}$ & $\mathrm{Ne}$ & $\mathrm{I}$ & $\mathrm{Ho}$ & $\mathrm{PIC}(\mathrm{He})$ & $\mathrm{F}$ & Range (bp) & $\mathrm{N}>5 \%$ \\
\hline dupssr26 & 6 & 2.6 & 1.179 & 0.629 & 0.616 & -0.021 & $113-145$ & 3 \\
bnlg1556 & 5 & 4.4 & 1.548 & 0.772 & 0.773 & 0.002 & $151-186$ & 5 \\
phi083 & 4 & 2.9 & 1.217 & 0.716 & 0.653 & -0.096 & $121-129$ & 4 \\
bnlg1520 & 9 & 3.2 & 1.463 & 0.802 & 0.691 & -0.161 & $161-196$ & 3 \\
umc1025 & 7 & 4.5 & 1.630 & 0.934 & 0.775 & -0.205 & $105-117$ & 5 \\
umc1109 & 4 & 2.6 & 1.038 & 0.737 & 0.615 & -0.198 & $103-115$ & 3 \\
bnlg2291 & 10 & 2.2 & 1.064 & 0.521 & 0.536 & 0.028 & $154-196$ & 6 \\
dupssr10 & 17 & 5.3 & 2.016 & 0.829 & 0.812 & -0.022 & $156-196$ & 4 \\
umc1792 & 5 & 1.7 & 0.835 & 0.135 & 0.419 & 0.676 & $113-124$ & 3 \\
umc1075 & 4 & 2.6 & 1.119 & 0.538 & 0.622 & 0.135 & $136-149$ & 4 \\
bnlg162 & 11 & 3.2 & 1.503 & 0.729 & 0.669 & -0.090 & $213-250$ & 6 \\
bnlg1209 & 7 & 1.9 & 1.056 & 0.316 & 0.464 & 0.319 & $169-196$ & 3 \\
\hline Mean & 7.4 & 3.1 & 1.306 & 0.638 & 0.637 & 0.031 & - & 4.1 \\
SE & 1.1 & 0.3 & 0.096 & 0.066 & 0.035 & 0.072 & - & 0.3 \\
\hline
\end{tabular}

$\mathrm{Na}$ - number of alleles per locus, $\mathrm{Ne}$ - number of effective alleles per locus, I - Shannon's information index, Ho - observed heterozygosity, PIC (He) - polymorphism information content (expected heterozygosity), F - inbreeding coefficient, bp - base pairs, $\mathrm{N}>5 \%$ - the number of alleles per locus excluding rare alleles, SE - standard error.

Genotypic data analyses included the following parameters: number of alleles per locus $(\mathrm{Na})$, number of effective alleles per locus $(\mathrm{Ne})$, Shannon's information index (I), observed heterozygosity (Ho), polymorphism information content (PIC) or expected heterozygosity $(\mathrm{He})$, fixation index $(\mathrm{F})$, the number of alleles per locus excluding rare alleles, and the average number of alleles specific to each group (private alleles). The microsatellite profiles of the hybrids were compared for increasing number of marker combinations and probabilities that two hybrids have the identical genotype (probability of identity) was calculated. The principal coordinate analysis (PCoA) was used to present the genetic relationship among hybrids via covariance matrix with data standardization. The genetic differentiation between groups from marker data was estimated with G-statistics (Jost, 2008; Nei, 1987). The pair-wise relatedness between hybrids was measured using Ritland's estimator (Ritland, 1996). The pedigreebased coefficient of parentage (COP) was used to estimate genetic distance among hybrids, assuming that each parent contributed equally to each progeny. The coefficient corresponds to the probability that alleles at a locus in two genotypes are identical by descent. The correlation between similarity matrices based on genetic distances obtained from marker and pedigree data was calculated using Mantel test. All the molecular diversity parameters obtained and abovementioned analyses were performed in GenAlEx 6.5 programme (Peakall \& Smouse, 2012).

\section{Results and Discussion}

The total number of alleles detected in 97 maize hybrids, analysed with twelve microsatellite markers, was 89 (Table 2). The majority of the markers were highly polymorphic. The number of alleles per locus ranged from 4, for markers phi083, umc1109 and umc1075, to 17, for dupssr10, with an average of 7.4 alleles. The relatively high number of identified alleles could be attributed to a higher proportion of markers with dinucleotide repeats. It also reflects a considerable diversity of the analysed hybrids. The detected number of alleles per locus (7.4) was lower than 8.2 alleles per locus, previously determined in 96 inbreds with 36 microsatellites (Mikic et al., 2017). It was also slightly higher than the number of alleles per locus obtained by Matsuoka et al. (2002), on 101 inbred lines with 46 SSRs (6.9), and much higher than those identified by Le Clerc et al. (2005), on the 178 maize cultivars with 51 SSRs (4.7), and by Jones et al. (2007), on 58 maize inbreds using 83 microsatellite markers (5.1). These differences in number of alleles per locus are due to different sample size, source of germplasm and repeat length of SSR. A noticeable number of rare alleles was scored. Almost $50 \%$ of all alleles had frequencies less than $5 \%$. Without the rare alleles, the average number of alleles was 4.1, which was still in line with majority assessed in previous studies. Although rare alleles are not very useful in revealing genetic relationship among genotypes and are usually excluded in association 
studies, they are very informative as indicators of breeding lineages, indicating high probability that shared rare alleles or haplotypes are identical by descent (Maccaferri et al., 2007; Romero-Severson et al., 2001).

The values of Shannon information index (I) exceeded 1 for almost all of the loci, implying high genetic diversity of the microsatellites. The loci with fewer alleles, but with more equal allele frequencies (e.g. umc1025) had higher values of information index and number of effective alleles than the loci with more alleles with unequal frequencies (e.g. bnlg2291 and bnlg1520). A mean value of inbreeding coefficient (F) was 0.031 . The negative values of inbreeding coefficient for seven markers indicated an excess of observed heterozygotes. On average, 64\% heterozygotes were observed. Except for umc1792 and bnlg1209, all the loci revealed a high percentage of heterozygote genotypes, allowing parent identification. The polymorphic information content (PIC) varied from 0.42, for umc1792 to 0.81 , for dupssr10, with an average of 0.64 Similar values of PIC or expected heterozygosity were found in previous research, varying from 0.62 to 0.69 (Jones et al., 2007; Le Clerc et al., 2005; Phumichai et al., 2008; Xu et al., 2004), with an exception of a significantly higher PIC value (0.89) reported in the study of Garcia et al. (2004).

A high PIC value of some locus indicates the presence of many alleles with approximately equal frequency. Considering a high proportion of rare alleles in our study, which caused unequal allele frequencies, the relatively high average PIC value was merely due to a large number of alleles of the majority of markers. The most informative markers, namely bnlg1556, umc1025, dupssr10, and bnlg162, had above average parameters of genetic diversity, such as the number of alleles with frequencies above $5 \%$, the number of effective alleles, Shannon information index, observed and expected heterozygosity. Relatively high parameters

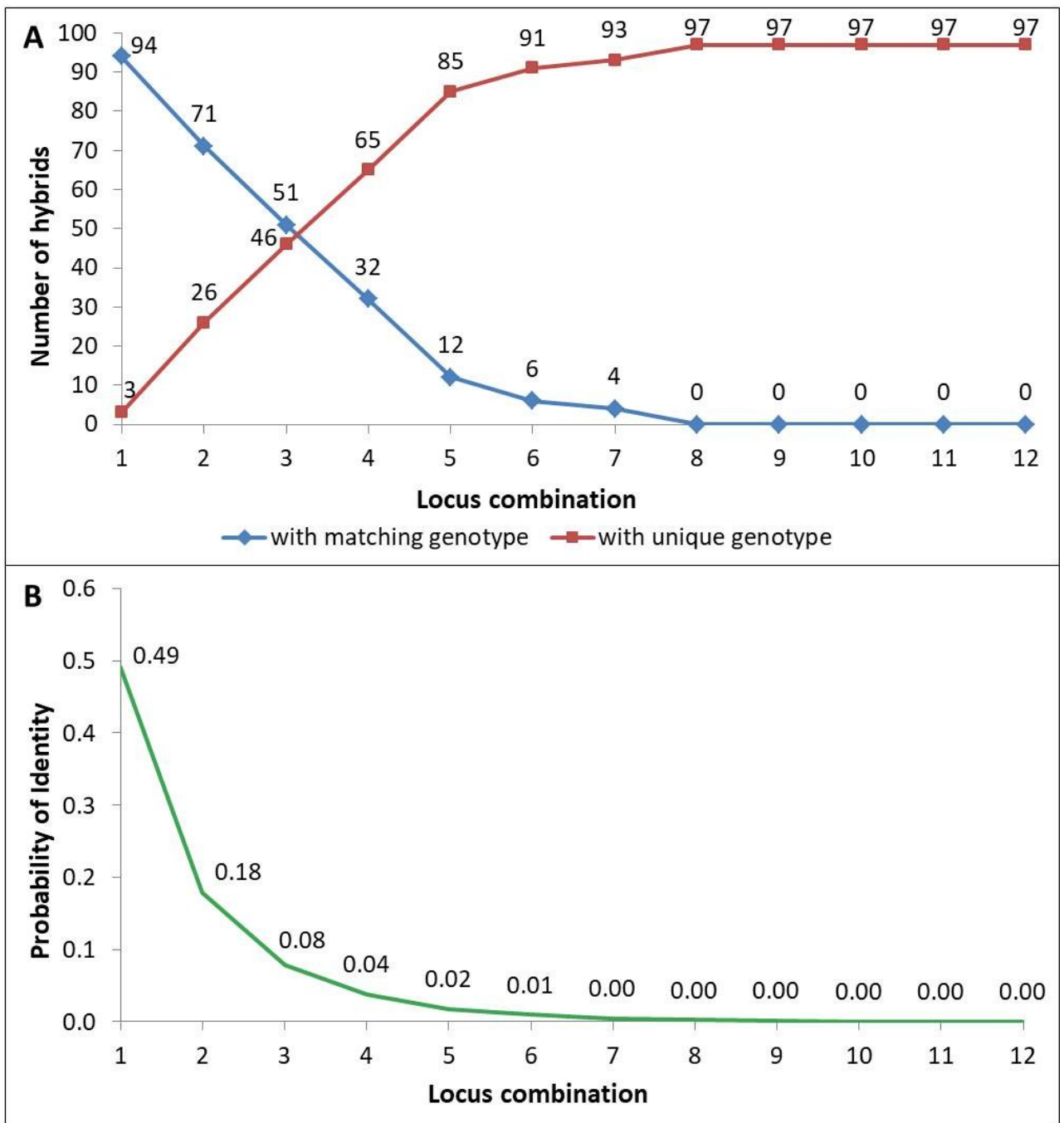

Figure 1. Multilocus matches (blue line) and unique by locus (red line) for increasing combinations of 12 loci (A), probability of identity including related individuals (green line) for 12 loci combinations (B). 


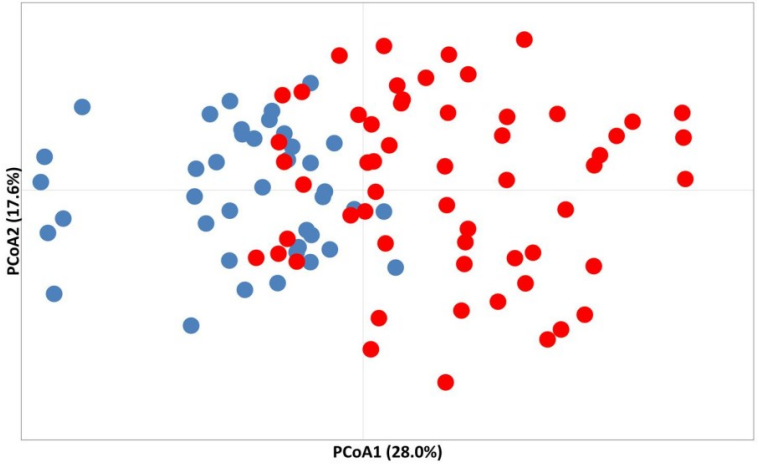

Figure 2. The principle coordinate analysis dividing FAO $\leq$ 490 hybrids (blue) and $\mathrm{FAO} \geq 500$ hybrids (red).

of genetic diversity implied that the majority of SSRs were polymorphic enough and thus suitable for diversity studies. They also showed a broad diversity of the analysed contemporary maize hybrids. This is in agreement with the research of Le Clerc et al. (2005), who found no evidence of reduction of genetic diversity in modern maize cultivars due to an influx of new alleles, which had been introduced through new genetic material in breeding programmes.

In order to estimate the ability of SSRs to discriminate between maize hybrids, the molecular profiles of the genotypes were compared for increasing number of locus combinations (Fig. 1). When the genotypes were screened with only one marker, three hybrids with unique alleles were distinguished. A combination of two markers enabled identification of 26 hybrids with unique allele combinations, while the 71 hybrids shared the same genotype for two loci. Distinct SSR profiles with a unique set of alleles for all 97 hybrids were obtained with eight microsatellites. The probability of identity revealed by microsatellite diversity patterns was sufficiently low to provide a reliable identification of individual hybrids. The probability of identity decreased as the number of marker combinations increased, reaching $1.15 \times 10^{-4}$ for 8 loci. Due to a high level of polymorphism of the microsatellites, a subset of only 8 markers facilitated individual hybrid identification with a high probability. A smaller number of markers, sufficient to determine the difference between the hybrids, indicated both greater diversity of the analysed hybrids and suitability of the selected markers for maize fingerprinting. Kozhukhova and Sivolap (2004) differentiated 40 unique molecular patterns of 40 maize genotypes with ten polymorphic SSR loci. In another study, 20 microsatellites revealed unique allelic combinations for 48 commercial maize single-cross hybrids, with a probability of identity ranging from $10^{-14}$ to $10^{-7}$ (Ribeiro et al., 2017).

The research on DNA fingerprinting have been focused far more on maize inbred lines than hybrids, particularly for plant variety protection, identification of essentially derived varieties and quality control genotyping. Chen et al. (2016) demonstrated that ten single nucleotide polymorphism markers (SNPs) could be employed in a rapid quality control for accurate and efficient identification of mislabelling, while 80 SNPs could be used in a broad quality control to verify the identity and purity of maize inbred lines and to evaluate the levels of their residual heterozygosity. In another study, 16 SNPs were sufficient to discriminate among 500 diverse inbreds (Jones et al., 2010). However, at least 100 SNPs were recommended for differentiation between closely related inbred lines. Similarly, Semagn et al. (2012) suggested between 50 and 100 SNPs for routine and low-cost quality control maize inbreds genotyping. A reliable identification of similarity thresholds for essentially derived varieties requires at least 100-150 highly polymorphic SSR markers (Heckenberger et al., 2005; Noli et al., 2013).

The pair-wise relatedness values using Ritland's coefficient varies from 0.787 to -0.129 , with an average -0.016 . A wide range of Ritland's coefficients showed that the markers revealed a good level of genetic diversity among the hybrids. The maximum value of Ritland's coefficient had two hybrids developed at the Institute of Field and Vegetable Crops (IFVCNS), Novi Sad, which corresponds to their pedigrees. Since the pedigrees of the analysed hybrids are not publicly available, it was not feasible to compare the coefficients with the pedigrees and interpret them for each hybrid pair.

Table 3. Means with standard errors of parameters of genetic diversity for early and late maturity groups of hybrids

\begin{tabular}{lcc}
\hline Group & Early maturing & Late maturing \\
\hline Number of alleles per locus & $6.92^{\mathrm{a}} \pm 0.89$ & $6.67^{\mathrm{a}} \pm 0.67$ \\
Number of alleles per locus with frequency $\geq 5 \%$ & $3.27^{\mathrm{a}} \pm 0.33$ & $3.38^{\mathrm{a}} \pm 0.29$ \\
Number of effective alleles per locus & $3.49^{\mathrm{a}} \pm 0.22$ & $2.83^{\mathrm{b}} \pm 0.15$ \\
Shannon's index & $1.34^{\mathrm{a}} \pm 0.11$ & $1.26^{\mathrm{a}} \pm 0.08$ \\
Number of private alleles per locus & $1.27^{\mathrm{a}} \pm 0.17$ & $0.82^{\mathrm{b}} \pm 0.11$ \\
Expected heterozygosity & $0.65^{\mathrm{a}} \pm 0.04$ & $0.63^{\mathrm{a}} \pm 0.03$ \\
\hline
\end{tabular}

Means with different superscript letters in the same rows are significantly different $(p<0.05)$ 


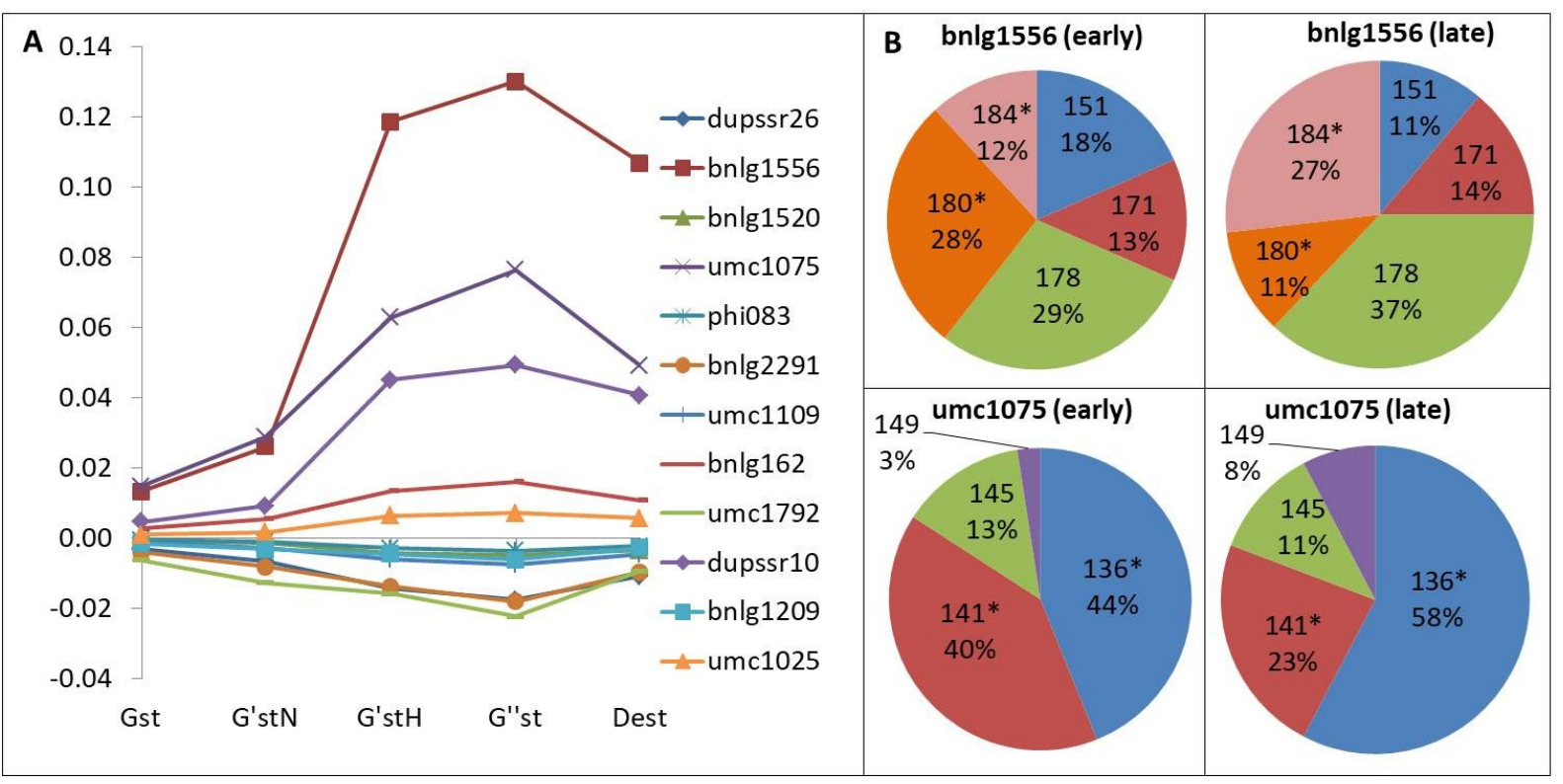

Figure 3. The coefficient of gene differentiation (Gst), Nei's standardized Gst (G'stN), Hedrick's standardized Gst (G'stH), Hedrick's further standardized Gst for small number of populations (G"st) and Jost's estimate of differentiation (Dest) for 12 microsatellite markers (A), allele frequencies comparison between early and late hybrid groups for markers bnlg1556 and umc1075 (B).

The principal coordinate analysis was applied to visualise and investigate the relationships among hybrids. The first principal coordinate accounted for $28.0 \%$, while the second coordinate explained $17.6 \%$ of the variation, together accounting for $45.6 \%$ of the total variation (Figure 2). The PCoA distinguished early and late maturing groups of hybrids. Forty one hybrids, of the FAO maturity groups from 200 to 490 , clustered together on the left side of the biplot, while 56 hybrids, belonging to FAO maturity groups from 500 to 700 , were positioned of the right side of the biplot. The differentiation between groups was not very high (Fst $=$ $0.4 \%)$, although significant $(p<0.05)$. In previous studies, principal component analyses based on molecular data divided the hybrids with contrasting heat unit rates (Sun et al., 2001) and relative maturity (Smith, 2007). In our study, a better differentiation of the hybrids by their maturity could presumably be achieved by including more microsatellites in the analysis. Our results suggest that the selection pressure for earliness did not reduce the diversity of the hybrids, probably due to diverse germplasm sources used in breeding programmes.

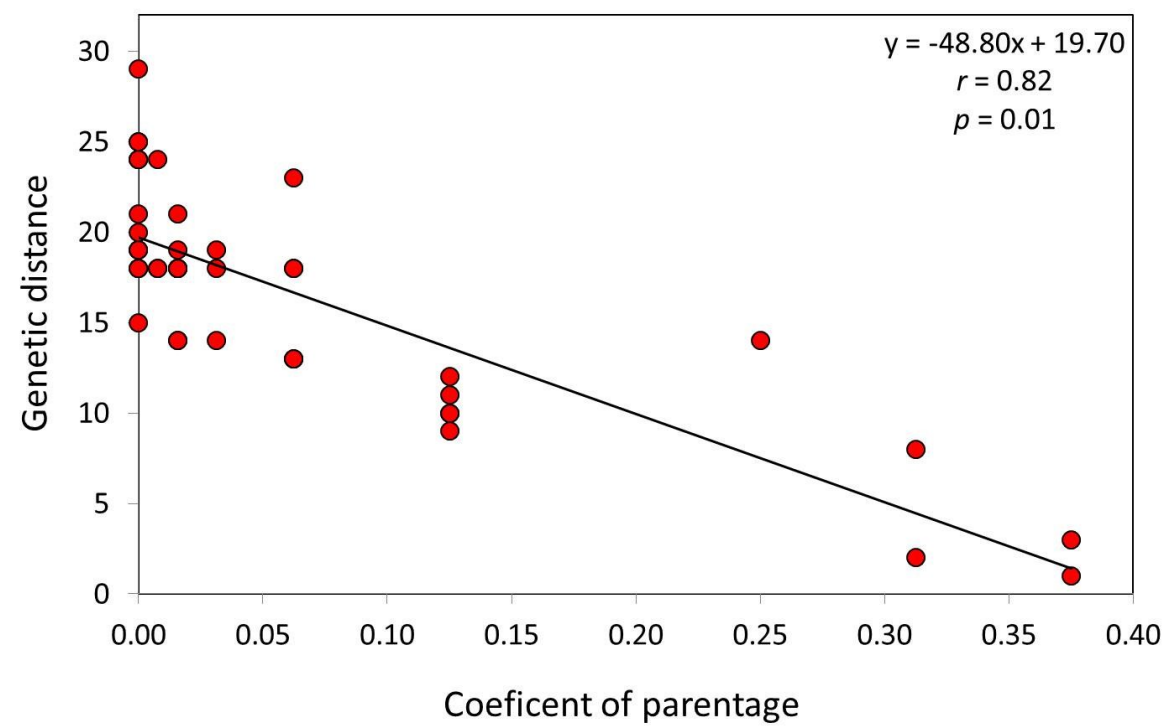

Figure 4. A correlation between distance matrices based on coefficients of parentage and microsatellite data (genetic distance) for the IFVCNS maize hybrids, obtained by Mantel test 
The group with early hybrids had significantly higher values for effective number of alleles and number of private (e. i. specific to only one group) alleles per locus (Table 3). The values of other parameters of genetic diversity did not differ significantly between the groups. The higher number of effective alleles in the early maturing group showed that there were more alleles with balanced frequencies among early hybrids than among the late ones. The significant difference in the number of private alleles per locus reflected distinction of the allelic profiles of two groups. In the early hybrids group, 14 private alleles were detected with 6 markers, with the highest average number of private alleles for dupssr10 (6), bnlg1556 (2) and bnlg1520 (2). Eleven private alleles were identified with 7 SSRs in the group of late hybrids. The most private alleles were scored with markers bnlg2291 (3), dupssr10 (2) and bnlg162 (2). In general, higher values of genetic diversity parameters in early maturing hybrids showed its broader genetic basis compared to the late maturing hybrids. Lübberstedt et al. (2000) accounted for a broad genetic base of early European maize, suggesting a wide range of sources used for developing breeding populations, adaption to cooler growing conditions without strong selection, and variation generated de novo through recombinations and mutations.

The genetic differentiation of the groups was estimated with five standardised estimators of genetic differentiation (Figure 3.) Based on these parameters, three markers, namely bnlg1556, umc1075 and dupssr10, contributed most to the separation of early and late genotypes. The differentiation was statistically significant for the first two markers. Two alleles of the markers bnlg1556 and umc1075 had significantly different frequencies between early and late maturing hybrids. The allele 180 of $b n \lg 1556$ and the allele 141 of umc1075 were more frequent among early maturing maize hybrids, whereas the allele 184 of bnlg1556 marker and the allele 136 of umc 1075 had higher frequencies in late maturing hybrids.

To determine a correlation between the genetic distances, estimated from the pedigrees and microsatellites, the coefficients of parentage for the IFVCNS hybrids with known pedigrees were calculated and compared with the pairwise codominant genetic distances based on microsatellite data using Mantel test (Figure 4). The correlation coefficient was significant and high $(r=0.82)$, as well within the scope of the coefficient values from previous studies, i.e. from 0.69 to 0.92 (Bernardo et al., 2000; Lübberstedt et al., 2000; Maccaferri et al., 2007).

A high coefficient of correlation between molecular and pedigree-based genetic similarities is a prerequisite for identification of essentially derived varieties (Heckenberger et al., 2005). Besides, the advantages of polymorphic SSRs in estimating molecular similarity due to identity by descent were demonstrated by Maccaferri et al. (2007). Romero-Severson et al. (2001) recommended a large set of well-distributed SSR markers to reduce a potential bias in pedigree analysis of maize due to a strong negative selection against alleles or positive selections for other alleles. Since an analysis of pedigree backgrounds is an important starting point to assess the available maize germplasm diversity for superior agronomic performance in certain environments (Smith et al., 2006), the complementary use of highly polymorphic microsatellite markers could considerably facilitate this endeavour.

\section{Conclusion}

The parameters of genetic diversity obtained with microsatellite markers showed a relatively large diversity of contemporary maize hybrids grown in Serbia. The majority of microsatellites was highly informative and proved useful in assessing genetic diversity and fingerprinting. Eight polymorphic SSRs demonstrated a good discriminatory power and may be considered sufficient to accurately differentiate all genotypes. However, for fingerprinting closely related genotypes, more markers ought to be applied. The principal coordinate analysis may satisfactorily differentiate early and late maturing hybrid groups. A better segregation and more detailed insight into genetic background of the tested hybrids could be achieved by increasing the number of markers. A significant correlation between molecular distances and pedigree-based distances demonstrates that the microsatellites could be a valuable tool to analyse parentage relationships, as well as to interpret, to complement and to confirm pedigree information.

\section{References}

Bernardo, R., Romero-Severson, J., Ziegle, J., Hauser, J., Joe, L., Hookstra, G., \& Doerge, R. W. (2000). Parental contribution and coefficient of coancestry among maize inbreds: pedigree, RFLP, and SSR data. Theoretical and Applied Genetics, 100(3-4), 552-556.

Buckler, E. S., Gaut, B. S., \& McMullen, M. D. (2006). Molecular and functional diversity of maize. Current Opinion in Plant Biology, 9:172176.

Chen, J., Zavala, C., Ortega, N., Petroli, C., Franco, J., Burgueño, J., Costich, D. E., \& Hearne, S. J. (2016). The development of quality control genotyping approaches: A case study using elite maize lines. PLoS One, 11(6), e0157236.

Duvick, D. N. (2001). Biotechnology in the 1930s: the development of hybrid maize. Nature Reviews Genetics, 2(1), 69-74.

Garcia, A. A., Benchimol, L. L., Barbosa, A. M., Geraldi, I. O., Souza Jr, C. L., \& Souza, A. P. D. (2004). Comparison of RAPD, RFLP, AFLP and SSR markers for diversity studies in tropical maize inbred lines. Genetics and Molecular Biology, 27(4), 579-588.

Guzman, P. S., \& Lamkey, K. R. (2000). Effective population size and genetic variability in the BS11 maize population. Crop Science, 40(2), 338-346.

Heckenberger, M., Bohn, M., Klein, D., \& Melchinger, A. E. (2005). Identification of Essentially Derived Varieties Obtained from Biparental Crosses of Homozygous Lines: II. Morphological Distances and Heterosis in Comparison with Simple Sequence Repeat and Amplified Fragment Length Polymorphism Data in Maize. Crop Science, 45:1132-1140.

Jones, E. S., Sullivan, H., Bhattramakki, D., \& Smith, J. S. (2007). A comparison of simple sequence repeat and single nucleotide polymorphism marker technologies for the genotypic analysis of maize (Zea mays L.). Theoretical and Applied Genetics, 115(3), 361-371. 
Jones, L., Wall, S., Nelson, B., \& Smith, S. (2010). Varietal identification in maize: are sixteen SNP markers sufficient? BMT/12/15 'Report on Developments in UPOV Concerning Biochemical and Molecular Techniques'. Twelfth Session of the Working Group on Biochemical and Molecular Techniques, and DNA Profiling in Particular, Ottawa, May 11-13, 2010.

Jost, L. (2008). GST and its relatives do not measure differentiation. Molecular Ecology, 17, 4015-4026.

Kozhukhova, N. E. \& Sivolap, Y. U. M. (2004). Identification and Registration of Maize Genotypes with the Use of Molecular Markers. Russian Journal of Genetics, 40(1), 49-55.

Le Clerc, V., Bazante, F., Baril, C., Guiard, J., \& Zhang, D. (2005). Assessing temporal changes in genetic diversity of maize varieties using microsatellite markers. Theoretical and Applied Genetics, 110(2), 294-302.

Lübberstedt, T., Melchinger, A. E., Dußle, C., Vuylsteke, M., \& Kuiper, M. (2000). IV. Genetic diversity revealed with AFLP markers and comparison with RFLP, RAPD Relationships among early European maize inbreds, and pedigree data. Crop Science, 40 (3), 783-791.

Maccaferri, M., Sanguineti, M. C., Xie, C., Smith, J. S. C., \& Tuberosa, R. (2007). Relationships among durum wheat accessions. II. A comparison of molecular and pedigree information. Genome, 50(4), 385-399.

Matsuoka, Y., Mitchell, S. E., Kresovich, S., Goodman, M., \& Doebley, J. (2002). Microsatellites in Zea - variability, patterns of mutations, and use for evolutionary studies. Theoretical and Applied Genetics, 104, 436-450.

Mikic, S., Kondic-Spika, A., Brbaklic, Lj., Stanisavljevic, D., Ceran, M., Trkulja, D., \& Mitrovic, B. (2017). Molecular and phenotypic characterisation of diverse temperate maize inbred lines in Southeast Europe. Zemdirbyste-Agriculture, 104(1), 31-40.

Nei, M. (1987). Molecular Evolutionary Genetics. New York: Columbia University Press.

Noli, E., Teriaca, M. S., \& Conti, S. (2013). Criteria for the definition of similarity thresholds for identifying essentially derived varieties. Plant Breeding, 132(6), 525-531.

Peakall R., \& Smouse P. E. (2012). GenAlEx 6.5: genetic analysis in Excel. Population genetic software for teaching and research - an update. Bioinformatics, 28(19), 2537-2539.

Phumichai, C., Doungchan, W., Puddhanon, P., Jampatong, S., Grudloyma, P., Kirdsri, C., \& Pulam, T. (2008). SSR-based and grain yield-based diversity of hybrid maize in Thailand. Field Crops Research, 108(2), 157-162.

Prasanna, B. M. (2012). Diversity in global maize germplasm: characterization and utilization. Journal of Biosciences, 37(5), 843-855.

Reif, J. C., Hamrit, S., Heckenberger, M., Schipprack, W., Maurer, H. P., Bohn, M., \& Melchinger, A. E. (2005). Trends in genetic diversity among European maize cultivars and their parental components during the past 50 years. Theoretical and Applied Genetics, 111(5), 838-845.

Ribeiro, C. A. G., Pinto, M. D. O., Maciel, T. E. F., Pastina, M. M., Barros, E. G. D., \& Guimarães, C. T. (2017). Universal tail sequence-SSR applied to molecular characterization of tropical maize hybrids. Scientia Agricola, 74(2), 163-168.

Ritland, K. (1996). Estimators for pairwise relatedness and individual inbreeding coefficients. Genetical Research, 67, 175-185.

Romero-Severson, J., Smith, J. S. C., Ziegle, J., Hauser, J., Joe, L., \& Hookstra, G. (2001). Pedigree analysis and haplotype sharing within diverse groups of Zea mays L. inbreds. Theoretical and Applied Genetics, 103(4), 567-574.

Semagn, K., Beyene, Y., Makumbi, D., Mugo, S., Prasanna, B. M., Magorokosho, C., \& Atlin, G. (2012). Quality control genotyping for assessment of genetic identity and purity in diverse tropical maize inbred lines. Theoretical and Applied Genetics, 125(7), 1487 1501.

Smith, J. S. C., Smith, O. S., Wright, S., Wall, S. J., \& Walton, M. (1992). Diversity of US hybrid maize germplasm as revealed by restriction fragment length polymorphisms. Crop Science, 32(3), 598-604.

Smith, J. S. C., Desbons, P., Gogerty, J., \& Niebur, W. S. (2006) Changes in parentage and genetic diversity of widely used maize hybrids grown in the northern United States and France from 1930 to the present. Maydica, 51(1), 57-77.

Smith, S. (2007). Pedigree background changes in US hybrid maize between 1980 and 2004. Crop Science, 47(5), 1914-1926.

Sun, G. L., William, M., Liu, J., Kasha, K. J., \& Pauls, K. P. (2001). Microsatellite and RAPD polymorphisms in Ontario corn hybrids are related to the commercial sources and maturity ratings. Molecular Breeding, 7(1), 13-24.

Tabanao, D. A., \& Bernardo, R. (2005). Genetic variation in maize breeding populations with different numbers of parents. Crop Science, 45(6), 2301-2306.

Technow F., Schrag T. A., Schipprack W., \& Melchinger A. E. (2014). Identification of key ancestors of modern germplasm in a breeding program of maize. Theoretical and Applied

Genetics, 127(12), 2545-2553.

Tenaillon, M. I. \& Charcosset, A. (2011). A European perspective on maize history. Comptes Rendus Biologies, 334(3), 221-228.

van de Wouw, M., van Hintum, T., Kik, C., van Treuren, R., \& Visser, B. (2010). Genetic diversity trends in twentieth century crop cultivars: a meta analysis. Theoretical and Applied Genetics, 120 (6), 1241-1252.

Xu, S. X., Liu, J., \& Liu, G. S. (2004). The use of SSRs for predicting the hybrid yield and yield heterosis in 15 key inbred lines of Chinese maize. Hereditas, 141, 207-215.

\section{Molekularni diverzitet i polimorfizam mikrosatelitskih markera savremenih hibrida kukuruza}

\section{Sanja Mikić · Ljiljana Brbaklić · Dušan Stanisavljević · Ankica Kondić-Špika · Goran Bekavac · Bojan Mitrović · Dragana Trkulja · Milan Mirosavljević}

Sažetak: Cilj ovog rada bio je da se proceni genetički diverzitet 97 savremenih hibrida kukuruza koji se gaje u Srbiji pomoću 12 mikrosatelitskih markera. Od ukupno 89 alela, prosečno je utvrđeno 7.4 alela po lokusu. Vrednost polimorfnosti pojedinačnih lokusa (PIC) kretala se od 0.42, za marker umc1792, do 0.81, za marker dupssr10, sa prosekom od 0.64. Vrednosti Ritlandovog koeficijenta srodnosti varirale su između 0.787 i - 0.129 . Osam markera je bilo dovoljno da razdvoji hibride sa jedinstvenim genotipovima. Analiza glavnih koordinata razdvojila je grupu ranih i grupu kasnih hibrida, iako je diferencijacija između grupa bila niska (Fst $=0.4 \%$ ). Dva markera, bnlg1556 i umc1075, su najviše doprinela razdvajanju ranih i kasnih genotipova. Vrednosti parametara molekularnog genetičkog diverziteta bile su veće kod ranih nego kod kasnih hibirida, što ukazuje na širu genetičku osnovu prve grupe. Visok nivo polimorfizma markera ukazuje na njihovu podobnost za određivanje molekularnog profila hibirida (tzv. fingerprinting).

Ključne reči: fingerprinting, genetički diverzitet, genotipizacija, hibridi, kukuruz, markeri, mikrosateliti, polimorfizam 